\title{
Scientific literature on Inga (Fabaceae) from Santa Catarina state, Southern Brazil (1983-2017)
}

\author{
Altamir Rocha Antunes*, Guilherme Alves Elias, Gisele Pezente \& Robson dos Santos \\ Herbário Pe. Dr. Raulino Reitz (CRI). Programa de Pós-Graduação em Ciências Ambientais, Universidade do \\ Extremo Sul Catarinense - UNESC, Criciúma, SC, Brasil; altamirmad@hotmail.com, guilherme@unesc.net, \\ gipezente@hotmail.com,rsa@unesc.net \\ * Correspondence
}

Received 08-X-2018. Corrected 19-VII-2019. Accepted 18-IX-2019.

\begin{abstract}
The genus Inga Mill. belongs to the mimosoid clade (Fabaceae, Caesalpinioideae) that includes 131 species in Brazil. It is the most important genus of Fabaceae. In this sense, this study aimed to perform a bibliometric analysis on Inga from Santa Catarina state. A survey of the published literature was conducted using the electronic databases of the Web of Science, Scopus and SciELO with the accepted names of Inga species and its synonyms. Papers were distributed in four subject categories: C1 (Ecological), C2 (morphology, anatomy, taxonomy, histology, physiology and genetics), $\mathrm{C} 3$ (production and use) and C4 (biochemical and nutritional properties). We registered 232 papers for 13 species of Inga. $\mathrm{C} 1$ was the most studied subject category, mainly in topics such as nutrient supply, shade and nitrogen fixing capacity. We also noticed that the subjects diversified over the years, with registered papers in all categories. Inga edulis, I. vera and I. marginata were the most registered species in our survey. Our results showed an increase in the number of articles on Inga over time, especially in the last 13 years. However, some important gaps need to be addressed, such as the relatively small number and/or lack of studies conducted for some species.
\end{abstract}

Key words: bibliometrics, Inga edulis, legumes, Ingeae.

Rocha Antunes, A., Alves Elias, G., Pezente, G., \& dos Santos, R. (2019). Scientific literature on Inga (Fabaceae) from Santa Catarina state, Southern Brazil (1983-2017). Revista de Biología Tropical, 67(6), 1247-1256.

The Fabaceae Lindl. (legumes) family is the richest in Brazil with 751 genus and 19000 species; it is one of the most representative in the world (Bruneau et al., 2013). Among them, Inga is the most expressive and larger genus of Ingeae (Possette \& Rodrigues, 2010). It can be distinguished from other genera for their arboreal habit, paripinnate leaves with nectary located between each pair of leaflets, fleshy and indehiscent fruits with seeds surrounded by a sweet and fleshy sarcotesta (Vasconcelos, 2014). Inga is exclusively neotropical and Brazil is one of the main centers of genetic diversity (Pennington, 1997). It has economic potential for reforestation, phytotherapy, energy production and food (Fernandes, Dondoni Da Costa, Araújo, \& Lopes, 2016). Besides that, legumes are essential for fertilization, fodder, wood, tannins, oils, resins in the manufacture of varnishes, paint and dyes and in horticultural trade (Gepts et al., 2005; LPWG, 2017).

As most information about Inga is being published and made available in electronic databases, studies have been focused on nitrogen fixation capacity (Yatazawa, Uchino, \& Hambali, 1983), shading plantations (Bishop, 1983; Staver, 1989; Alegre \& Rao, 1996; Kettler, 1996), medicinal potential (Tauchen et al., 
2016) and nutritional and biochemical properties (Lima, Santos, \& Porta, 2018). Bibliometric studies are very important and are being increasingly used to measure and analyze the scientific development in a specific research field (Hood \& Wilson, 2001; Elias, Corrêa, Citadini-Zanette, \& Santos, 2015).

The state of Santa Catarina has been a pioneer in the study of its forests and flora, exemplified by the Illustrated Flora of Santa Catarina - one of the most comprehensive works on Brazilian plants - developed by Reitz (1965), and the Barbosa Rodrigues Herbarium (HBR). Currently, the Floristic and Forest Inventory of Santa Catarina (IFFSC) (Vibrans, Sevegnani, Gasper, \& Lingner, 2012a; Vibrans, Sevegnani, Gasper, \& Lingner, 2012b; Vibrans, Sevegnani, Gasper, Müller, \& Reis et al. 2013a; Vibrans, Sevegnani, Gasper, \& Lingner, 2013b; Vibrans, Sevegnani, Gasper, \& Lingner, 2013c) is responsible of disseminating current comprehensive data on Santa Catarina forest flora. In this context, this paper aimed to carry out a bibliometric analysis of the genus Inga naturally occurring in Santa Catarina, southern Brazil. We expect that our results may provide support for future researches on Inga species in Brazil.

Literature reviewed: The survey of the published literature on Inga was conducted using the databases Web of Science, Scopus and SciELO. Accepted names and the synonyms of naturally occurring species in Santa Catarina (Tropicos, 2013; Flora do Brasil 2020 Under Contruction, 2019) were used as keywords (Table 1). The search was performed in March 2018 and all papers published until December 31st, 2017 were compiled.

As mentioned before, the study area is located in the state of Santa Catarina, southern Brazil because Inga has great representation in the tree component in this area (Burkart, 1979). However, few articles deal specifically with the genus in the state. The Köppen climate classification for Santa Catarina is humid subtropical with no defined dry season and hot summers $(\mathrm{Cfa})$ or balmy summers $(\mathrm{Cfb})$, corresponding to 40 and $60 \%$ of the study

TABLE 1

Inga species distributed in Santa Catarina with its synonyms and vernacular names

TABLA 1

Especies de Inga distribuidas en Santa Catarina con sus sinónimos y nombres vernaculares

\begin{tabular}{lll}
\multicolumn{1}{c}{ Accepted names } & \multicolumn{1}{c}{ Synonyms } & \multicolumn{1}{c}{ Vernacular names } \\
Inga edulis Mart. & Inga scabriuscula Benth. & ingá-cipó \\
Inga edwallii (Harms) T.D.Penn. & none & ingá \\
Inga lentiscifolia Benth. & none & ingá \\
Inga marginata Willd. & none & ingá-feijão \\
Inga sellowiana Benth. & none & ingá-ferro \\
Inga sessilis (Vell.) Mart. & none & ingá-macaco \\
Inga striata Benth. & Inga nuda Salzm. & ingá-quadrado \\
& Inga salzmanniana Benth. & ingá \\
Inga subnuda Salzm. ex Benth. & & ingá \\
Inga subnuda subsp. luschnathiana (Benth.) T.D.Penn. & Inga luschnathiana Salzm. ex Benth. \\
Inga vera Willd. & Inga spuria Humb. \& Bonpl. ex Willd. & ingá-do-brejo \\
Inga vera subsp. affinis (DC.) T.D.Penn. & Inga arinensis Hoehne & ingá \\
& Inga meissneriana Miq. & \\
& Inga uraguensis Hook. \& Arn. & \\
Inga virescens Benth. & Inga uruguensis Hook. \& Arn. & \\
Inga vulpina Mart. ex Benth. & Inga affinis DC. & ingá-torcido \\
\hline
\end{tabular}


TABLE 2

Study categories for Inga species distributed in Santa Catarina

TABLA 2

Categorías de estudio para las especies de Inga distribuidas en Santa Catarina

\begin{tabular}{|c|c|c|}
\hline Category & Study categories & Description \\
\hline $\mathrm{C} 1$ & Ecological & $\begin{array}{l}\text { Floristics, phytosociology, phenology, conservation, } \\
\text { population dynamics and interactions. }\end{array}$ \\
\hline $\mathrm{C} 2$ & Biological properties & Morphology, anatomy, histology, taxonomy, plant physiology and genetics. \\
\hline $\mathrm{C} 3$ & Production and use & $\begin{array}{l}\text { Production and transformation of forest products, } \\
\text { use by communities or commercialization. }\end{array}$ \\
\hline $\mathrm{C} 4$ & $\begin{array}{l}\text { Biochemical and } \\
\text { nutritional properties }\end{array}$ & $\begin{array}{l}\text { Plant services used as feedstock for the isolation of one } \\
\text { or more biochemical substances. }\end{array}$ \\
\hline
\end{tabular}

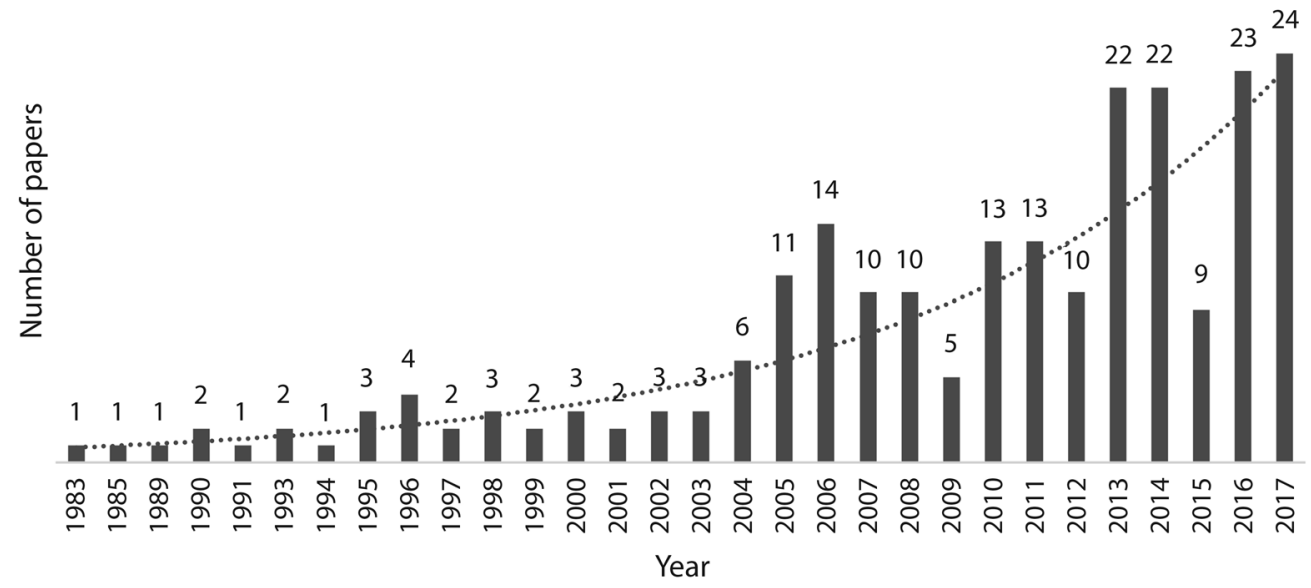

Fig. 1. Scientific production overview on Inga species distributed in Santa Catarina, southern Brazil.

Fig. 1. Producción científica sobre especies de Inga distribuidas en Santa Catarina, sur de Brasil.

area respectively (Alvares, Stape, Sentelhas, Gonçalves, \& Sparovek, 2013). Rainfall is well distributed throughout the state with an annual average of $1250-2000 \mathrm{~mm} /$ year with no areas of regular drought (Nimer, 1990). Each paper was identified by: (i) the year of publication, (ii) the scientific journal of publication, (iii) authors and (iv) study categories (Table 2) (Elias et al., 2015).

Trends in the literature: We found 232 papers for 13 species of Inga between 1983 and 2017. (Fig. 1). All papers were distributed in 133 scientific journals from different locations. All articles resulted in 934 collaborations among the 232 articles.

From 1983 to 1989 few papers were published and, for many years, no papers appeared on the subject. During this period, papers were mainly focused in the genus consortium with other species, highlighting the supply of nutrients and shading, which increases the yield of productions of coffee, cocoa and banana (Bishop, 1983; Staver, 1989). The following decade, publications maintained the same trend. Exceptionally, in 1996, the amount of articles published increased. At this time, papers called attention on the consortium between Inga and 
monocultures, such as beans and rice (Alegre \& Rao, 1996; Kettler, 1996).

From the year 2000 until 2010, the number of papers grew: in 2006, 14 papers were published, mainly on biochemical and nutritional properties of Inga (Arévalo-Pinedo, Dos Santos, Salles Arévalo, Zuniga, \& Pinedo, 2006; Faria et al., 2006). These works dealt with Inga's increase in nutritional compounds as well as its conservation of germplasm. Despite the rise in publications, 2009 showed a decrease. The articles focused on Inga's ecological relation with other organisms, such as the preference of birds for Inga species (Fink, Lindell, Morrison, Zahawi, \& Holl, 2009).

During the years 2010-2017, we registered the highest scientific production on Inga. Most papers were focused on properties of secondary metabolism and applications in plant biological activities (De Sousa Dias, De Souza, \& Rogez, 2010; Pinto, Souza, \& Oliveira, 2010). The scientific production decreased exclusively in 2012 and 2015. However, they followed the same trend, where they focused on exploring the biochemical properties of Inga and their applications (dos Santos Barros, do Nascimento, \& de Azevedo, 2012; Guillermo-Ferreira, Cardoso-Leite, \& Gandolfo, 2012; De Freitas et al., 2015; Nygren \& Leblanc, 2015).

Over the years, the growth in scientific production has been intensified in several areas of knowledge, such as ecology, biological activities, production and phytochemistry (De Sousa Dias et al., 2010; da Silva et al., 2014; Lamarca \& Barbedo, 2015; Avila Jr., Pinheiro, \& Sazima, 2015; Machado, de Oliveira, Zério, Parra, \& Macedo, 2017). All papers were distributed in 133 scientific journals in several areas of knowledge. Agroforestry Systems was the main journal with 17 published papers, followed by Forest Ecology and Management (8), Revista Árvore (7), Rodriguésia (7) and Biotropica (6). These journals published articles on Forest Sciences, particularly the environment and nature conservation, forestry, use of forest products, taxonomy and forest management. Our results suggest a relatively dispersed paper distribution, where $19.6 \%$ represents the five most influential journals. Other papers were distributed between one or two publications per journal.

The most productive author on Inga was Barbedo (on plant physiology) with 12 papers, followed by Leblanc (plant breeding) and Rogez (interactions of phenolic compounds) with nine papers each, Nygren (ecophysiology) with eight papers and Holl (restoration ecology) with six papers. On the other hand, the five most representative authors (those who have published more than six papers) mainly were focused on $\mathrm{Cl}$, the most representative in this study with 178 papers (Fig. 2). In this class, we found several research lines in ecological approaches, such as the floristic composition and phytosociological structure of a riparian forest in Southern Brazil, where Inga marginata was one of the most important species in the sample (Nakajima, Soares-Silva, Medri, Goldenberg, \& Correa, 1996). Another study evaluated Inga edulis in processes of increasing soil fertility, highlighting its positive

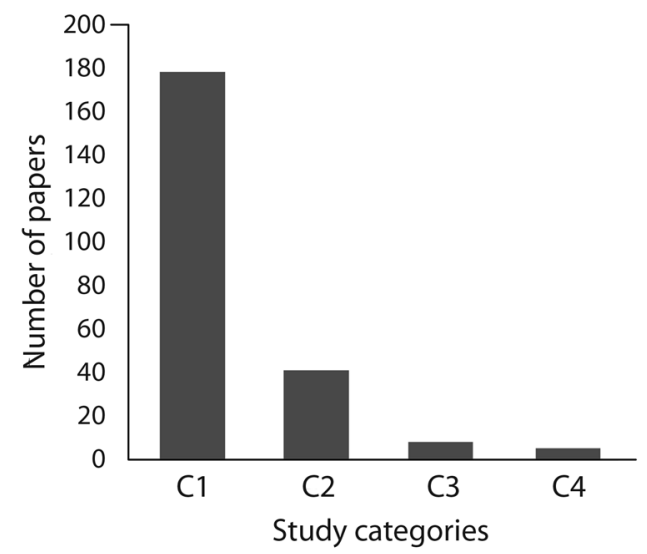

Fig. 2. Distribution of published papers per study categories on Inga species distributed in Santa Catarina, southern Brazil. C1 - Ecological; C2 - Morphology, anatomy, histology, taxonomy physiology and genetics; C3 - Production and use; C4 - Biochemical and nutritional properties.

Fig. 2. Distribución de artículos publicados por categoría de estudio sobre especies de Inga distribuidas en Santa Catarina, sur de Brasil. C1 - Ecológico; C2 - Morfología, anatomía, histología, taxonomía, fisiología y genética; C3 - Producción y uso; C4 - Propiedades bioquímicas y nutricionales. 
performance (Kanmegne, Bayomock, Duguma, \& Ladipo, 2000). Also, some studies called out Inga's ability to resist disturbances such as herbivory (Thomaz Heerdt \& Ferreira de Melo Junior, 2016) and herbicides (Cabral et al., 2017), besides facilitating regeneration of forests due to mycorrhizal associations (Iglesias, Salas, Leblanc, \& Nygren, 2011; Nygren, Leblanc, Lu, \& Luciano, 2013).

Conversely, $\mathrm{C} 4$ was the second place most researched field with 41 species, such as Inga edulis, Inga vera and Inga marginata (Fig. 2). The studies pointed out that Fabaceae is well known for the compounds of the secondary metabolism and their use in biological assays (Molares \& Ladio, 2012). The majority of studies were published from 2010 onwards and they highlighted the active principles of Inga species (Lima et al., 2018). Research with methanolic extracts of the barks, leaves, and flowers of Inga marginata evidenced reduction of the severity of anthracnose in bean plantations to values below $35 \%$ observed in the control group (Andrade Pinto, Souza, \& Oliveira, 2010). Chemical studies showed phenolic compounds on the leaves of genus Inga used in traditional medicine as laxatives. On the other hand, another study shows that the leaves of Inga edulis, I. marginata and I. laurina presented high antioxidant capacity, probably related to the presence of phenolic substances (Lima et al., 2018).

These types of studies are important precursors for investigations on biological activities (Antunes, 2018). For instance, indigenous communities use Inga species for inflammation and rheumatism as reported in an ethnobotanical study (Lima et al., 2018). Besides that, it is a much appreciated genus in Northern Brazil as food, whereby it is important to know their nutritional values. Those studies have shown that some of its secondary compounds have a high content of phenolic compounds, elevating its pharmacological potential, especially its antioxidant capacity (Pompeu, Rogez, Monteiro, Tinti, \& Carvalho, 2012). Inga edulis, particularly, exhibited a high content of phenolic compounds and high antioxidant capacity, capable of having antiulcerogenic activity (Pompeu et al., 2012). I. vera, on the other hand, provides a defense strategy - with peptidase inhibitors - that interferes in the physiology of insects. This mechanism has been considered as a biotechnological alternative for the control of pests (Bezerra, Oliveira, \& Macedo, 2017).

We also registered eight papers on the $\mathrm{C} 2$ category (Fig. 2). In general, it is an underrepresented class; however, it is very relevant for the research line, particularly taxonomic studies (Rapini, 2004). Other papers investigated germination capacities, its break of dormancy and seed viability (Parisi, Biagi, Medina, \& Barbedo, 2016; Delgado, Da Silva, \& da Silva, 2017). On the other hand, C3 was the least representative class of our sample, with only five published papers (Fig. 2). All of them focused on timber and food uses (Clement, CristoAraújo, Eeckenbrugge, Pereira, \& PicançoRodrigues, 2010; Lopes, Crepaldi, \& Lobão, 2017; de Freitas et al., 2018).

The species Inga edulis, I. vera and I. marginata were the most cited species in our study, mainly in $\mathrm{C} 1$ class (Table 3 ). Inga edulis is a tree naturally distributed in tropical America, largely known by its wood quality and used, in Brazil, for food and shading of coffee plantations (Burkart, 1979). The strong ecological interactions, highlighted in our results, were related to animals, especially birds (Lindell, Reid, \& Cole, 2013). Besides that, some studies emphasize the dispersers preference for I. edulis than other tree species in the same environment (Lindell et al., 2013). In addition, it shows antioxidant activities with moderate biological activities (Souza et al., 2007; De Freitas et al., 2018).

Studies on I. vera followed the same pattern of I. edulis: it stands out as a preferential diet for birds (Ragusa-Netto, 2004), and other ecological interactions. Patterns between morphological parameters of birds and flowers of Inga suggests a close mutualistic and complex relationship of pollination and environment (Githiru, Lens, Bennur, \& Ogol, 2002; Cruz-Neto, Machado, Duarte Jr, \& Lopes, 
TABLE 3

Number of papers registered per species and study categories

TABLA 3

Número de artículos registrados por especie y categorías de estúdio

\begin{tabular}{lcccc}
$\quad$ Species & $\mathrm{C} 1$ & $\mathrm{C} 2$ & $\mathrm{C} 3$ & $\mathrm{C} 4$ \\
Inga edulis Mart. & 86 & 2 & 3 & 31 \\
Inga edwallii (Harms) T.D.Penn. & 0 & 0 & 0 & 0 \\
Inga lentiscifolia Benth. & 1 & 0 & 0 & 0 \\
Inga marginata Willd. & 22 & 0 & 0 & 4 \\
Inga sellowiana Benth. & 0 & 0 & 0 & 0 \\
Inga sessilis (Vell.) Mart. & 3 & 0 & 0 & 0 \\
Inga striata Benth. & 5 & 0 & 0 & 0 \\
Inga subnuda Salzm. ex Benth. & 8 & 0 & 1 & 1 \\
Inga subnuda subsp. luschnathiana (Benth.) T.D.Penn. & 2 & 0 & 0 & 0 \\
Inga vera Willd. & 45 & 4 & 1 & 5 \\
Inga vera subsp. affinis (DC.) T.D.Penn. & 5 & 2 & 0 & 0 \\
Inga virescens Benth. & 1 & 0 & 0 & 0 \\
Inga vulpina Mart. ex Benth. & 0 & 0 & 0 & 0 \\
Total & $\mathbf{1 7 8}$ & $\mathbf{8}$ & $\mathbf{5}$ & $\mathbf{4 1}$ \\
\hline
\end{tabular}

2011). I. marginata also stood out in ecological approaches, exhibiting potential as a facilitator of natural regeneration in the Atlantic Forest, with the highest number of species growing under its individuals (Spadeto, Wilson Fernandes, Negreiros, \& Kunz, 2017) as well as I. edulis and I. vera. Besides that, I. marginata has potential for phytoremediation, being used for ecological restoration, especially in environments contaminated by herbicides (Cabral et al., 2017).

Finally, few investigations have been conducted on I. lentiscifolia, I. sessilis, I. striata, I. subnuda, I. subnuda subsp. luschnathiana, I. vera subsp. affinis, I. virescens, while no published paper were found for I. edwallii, I. sellowiana and I. vulpina. These species are more restrict, occurring in a few places in Santa Catarina. In this context, the bibliometric analysis showed an increase in the number of papers on Inga over time, especially in the last 13 years. However, some important gaps need to be addressed, such as the relatively small number and/or lack of studies conducted for some species. In addition, we expect that more researches will be performed with Inga, emphasizing the less studied categories and species to reveal the real potential of this genus in Santa Catarina.

\section{ACKNOWLEDGMENTS}

We acknowledge financial support from the Coordination for the Improvement of Higher Education Personnel (FAPESC/CAPES) for the first author's scholarship funding and the Universidade do Extremo Sul Catarinense (UNESC) for infrastructure.

\section{RESUMEN}

Literatura científica sobre Inga (Fabaceae) en el estado de Santa Catarina al sur de Brasil (1983-2017). El género Inga Mill. pertenece al clado mimosoide (Fabaceae, Caesalpinioideae) con 131 especies en Brasil. Es el género más importante de las Fabáceas. En este sentido, el objetivo de este estudio fue realizar un análisis bibliométrico de Inga en el Estado de Santa Catarina. Se condujo un estudio de la literatura publicada utilizando las bases de 
datos electrónicas de la Web of Science, Scopus y SciELO con los nombres aceptados de las especies Inga y sus sinónimos. Los trabajos se distribuyeron en cuatro categorías temáticas: C1 (ecológico), C2 (morfología, anatomía, taxonomía, histología, fisiología y genética), C3 (producción y uso) y C4 (propiedades bioquímicas y nutricionales). Se registraron 232 trabajos para 13 especies de Inga, donde se exhibió un notable incremento de publicaciones. $\mathrm{C} 1$ fue la categoría temática más estudiada, principalmente en temas tales como: suministro de nutrientes, sombra y capacidad de fijación de nitrógeno. Inga edulis, I. vera e I. marginata fueron las especies más registradas en nuestro estudio. Nuestros resultados mostraron un aumento en el número de artículos sobre Inga con el tiempo, especialmente en los últimos 13 años. Sin embargo, es necesario abordar algunos vacíos importantes como el número relativamente pequeño y/o la falta de estudios realizados para algunas especies.

Palabras clave: bibliometría, Inga edulis, legumbres, Ingeae.

\section{REFERENCES}

Alegre, J. C., \& Rao, M. R. (1996). Soil and water conservation by contour hedging in the humid tropics of Peru. Agriculture, Ecosystems \& Environment, 57(1), 17-25. DOI: https://doi.org/https://doi. org/10.1016/0167-8809(95)01012-2

Andrade Pinto, J. M., Souza, E. A., \& Oliveira, D. F. (2010). Use of plant extracts in the control of common bean anthracnose. Crop Protection, 29(8), 838842. DOI: https://doi.org/https://doi.org/10.1016/j. cropro.2010.03.006

Alvares, C. A., Stape, J. L., Sentelhas, P. C., Gonçalves, J. L. M., \& Sparovek, G. (2013). Köppen's climate classification map for Brazil. Meteorologische Zeitschrift, 22(6), 711-728. DOI: https://doi.org/https:// doi.org/10.1127/0941-2948/2013/0507

Antunes, A. R., \& Citadini-Zanette, V. (2018). Erythrina falcata Benth. (Fabaceae): Estudo Etnobotânico, Fitoquímico e Biológico. Revista Brasileira de Agroecologia, 13(14), 192-193.

Arévalo-Pinedo, A., Dos Santos, F. L., Salles Arévalo, Z. D., Zuniga, A. D. G., \& Pinedo, R. A. (2006). Desorption isotherms for murici (Byrsonima sericea) and Inga (Inga edulis) pulps. Journal of Food Engineering, 76(4), 611-615. DOI: https://doi.org/10.1016/j. jfoodeng.2005.06.011

Ávila Jr., R., Pinheiro, M., \& Sazima, M. (2015). The generalist Inga subnuda subsp. luschnathiana (Fabaceae): negative effect of floral visitors on reproductive success? Plant Biology, 17(3), 728-733. DOI: https://doi. org/10.1111/plb.12291
Bezerra, C. D. S., Oliveira, C. T., \& Macedo, M. L. R. (2017). Inga vera trypsin inhibitor interferes in the proteolytic activity and nutritional physiology of Ephestia kuehniella larvae. Entomologia Experimentalis et Applicata, 165(2-3), 109-119. DOI: https:// doi.org/10.1111/eea.12605

Bishop, J. P. (1983). Tropical forest sheep on legume forage/fuelwood fallows. Agroforestry Systems, 1(2), 79-84. DOI: https://doi.org/10.1007/BF00596350

Bruneau, A., Doyle, J. J., Herendeen, P., Hughes, C., Kenicer, G., Lewis, G., ... Pennington, T. (2013). Legume phylogeny and classification in the 21 st century: Progress, prospects and lessons for other speciesrich clades. Tiina Särkinen TAXON, 6281921(622), 217-248.

Burkart, A. (1979). Leguminosas Mimosoideas. Itajaí, Brasil: Flora Ilustrada Catarinense.

Cabral, C. M., dos Santos, J. B., Ferreira, E. A., Machado, V. M., Pereira, I. M., Silva, D. V., \& Souza, M. F. (2017). Tolerance to the herbicide clomazone and potential for changes of forest species. Bioscience Journal, 33(4), 897-904. DOI: https://doi. org/10.14393/BJ-v33n4a2017-36750

Clement, C. R., de Cristo-Araújo, M., d'Eeckenbrugge, G. C., Pereira, A. A., \& Picanço-Rodrigues, D. (2010). Origin and domestication of native Amazonian crops. Diversity, 2(1), 72-106. DOI: https://doi.org/10.3390/ d201007210.1371/journal.pone.0003311

Cruz-Neto, O., Machado, I. C., Duarte Jr., J. A., \& Lopes, A. V. (2011). Synchronous phenology of hawkmoths (Sphingidae) and Inga species (FabaceaeMimosoideae): Implications for the restoration of the Atlantic forest of northeastern Brazil. Biodiversity and Conservation, 20(4), 751-765. DOI: https://doi. org/10.1007/s10531-010-9975-x

Da Silva, K., De Meyer, S. E., Rouws, L. F., Farias, E. N., dos Santos, M. A., O'Hara, G., ... Zilli, J. E. (2014). Bradyrhizobium ingae sp. nov., isolated from effective nodules of Inga laurina grown in Cerrado soil. International Journal of Systematic and Evolutionary Microbiology, 64, 3395-3401. DOI: https://doi. org/10.1099/ijs.0.063727-0

Da Silva Possette, R. F., \& Rodrigues, W. A. (2010). O gênero Inga Mill. (Leguminosae - Mimosoideae) no estado do Paraná, Brasil. Acta Botanica Brasilica, 24(2), 354-368. DOI: https://doi.org/10.1590/ S0102-33062010000200006

De Freitas, F. A., Araujo, R. C., Soares, E. R., Nunomura, R. C. S., da Silva, F. M. A., da Silva, S. R. S., ... Koolen, H. H. F. (2018). Biological evaluation and quantitative analysis of antioxidant compounds in pulps of the Amazonian fruits bacuri (Platonia insignis Mart.), inga (Inga edulis Mart.), and uchi (Sacoglottis uchi Huber) by UHPLC-ESI-MS/MS. 
Journal of Food Biochemistry, 42(1). DOI: https:// doi.org/10.1111/jfbc. 12455

De Freitas, T. A., Franca, M. G. C., de Almeida, A. A. F., de Oliveira, S. J. R., de Jesus, R. M., Souza, V. L., ... Mangabeira, P. A. (2015). Morphology, ultrastructure and mineral uptake is affected by copper toxicity in young plants of Inga subnuda subs. luschnathiana (Benth.) TD Penn. Environmental Science and Pollution Research, 22(20), 15479-15494. DOI: https:// doi.org/10.1007/s11356-015-4610-8

De Sousa Dias, A. L., De Souza, J. N. S., \& Rogez, H. (2010). Purification of phenolic compounds from Inga edulis leaves using solid-phase extraction: major compounds quantification and antioxidant capacity evaluation. Quimica Nova, 33(1), 38-42.

De Vasconcelos, G. C. L. (2014). A tribo Ingeae Benth. (Mimosoideae, Leguminosae) no Estado da Paraíba (Master's thesis). Universidade Federal de Viçosa, Minas Gerais, Brazil.

Delgado, L. G. M., Da Silva, R. B. G., \& da Silva, M. R. (2017). Morphological quality of Inga vera seedlings under different water managements. IRRIGA, 22(3), 420-429. DOI: https://doi.org/10.15809/ irriga.2017v22n3p420-429

Dos Santos Barros, S. V, do Nascimento, C. C., \& de Azevedo, C. P. (2012). Energetic characterization of native and exotic forest species cultivated at Amazonas. Floresta, 42(4), 725-732.

Elias, G. A., Corrêa, P., Citadini-Zanette, V., \& Santos, R. (2015). Arecaceae: Análise bibliométrica das espécies nativas do estado de Santa Catarina. Ciência e Natura, 37(1), 85-92. DOI: https://doi. org/10.5902/2179460X15399

Faria, J. M. R., Davide, L. C., Da Silva, E. A. A., Davide, A. C., Pereira, R. C., van Lammeren, A. A. M., \& Hilhorst, H. W. M. (2006). Physiological and cytological aspects of Inga vera subsp. affinis embryos during storage. Brazilian Journal of Plant Physiology, 18(4), 503-513. DOI: https://doi.org/10.1590/ S1677-04202006000400008

Fernandes, J. M., Dondoni Da Costa, R., Araújo, C. R., \& Lopes, S. (2016). Taxonomia de Inga macrophylla Humb. \&amp; Bonpl. ex Willd. (Leguminosae, Mimosoideae): Uma Nova Ocorrência Para Mato Grosso, Brasil. Enciclopédia Biosfera, 13(24), 1329-1335. DOI: https://doi.org/10.18677/ EnciBio_2016B_123

Fink, R. D., Lindell, C. A., Morrison, E. B., Zahawi, R. A., \& Holl, K. D. (2009). Patch size and tree species influence the number and duration of bird visits in forest restoration plots in southern Costa Rica. Restoration Ecology, 17(4), 479-486. DOI: https://doi. org/10.1111/j.1526-100X.2008.00383.x
Flora do Brasil 2020. (2019). Jardim Botânico do Rio de Janeiro. Recuperado de http://floradobrasil.jbrj.gov. br

Gepts, P., Beavis, W. D., Brummer, E. C., Shoemaker, R. C., Stalker, H. T., Weeden, N. F., \& Young, N. D. (2005). Legumes as a model plant family. Genomics for food and feed report of the Cross-Legume Advances Through Genomics Conference. Plant Physiology, 137(4), 1228-1235. DOI: https://doi.org/10.1104/ pp.105.060871

Githiru, M., Lens, L., Bennur, L. A., \& Ogol, C. P. K. O. (2002). Effects of site and fruit size on the composition of avian frugivore assemblages in a fragmented afrotropical forest. Oikos, 96(2), 320-330. DOI: https://doi.org/10.1034/j.1600-0706.2002.960214.x

Guillermo-Ferreira, R., Cardoso-Leite, R., \& Gandolfo, R. (2012). First observation of alternative food usage (extrafloral nectar) by the assassin bug Atopozelus opsimus (Hemiptera, Reduviidae). Revista Brasileira de Entomologia, 56(4), 489-491. DOI: https://doi. org/10.1590/S0085-56262012000400001410.1111/ j.1463-6395.2011.00522.x

Hood, W. W., \& Wilson, C. S. (2001). The literature of bibliometrics, scientometrics, and informetrics. Scientometrics, 52(2), 291-314. DOI: https://doi. org/10.1023/A:1017919924342

Iglesias, L., Salas, E., Leblanc, H. A., \& Nygren, P. (2011). Response of Theobroma cacao and Inga edulis seedlings to cross-inoculated populations of arbuscular mycorrhizal fungi. Agroforestry Systems, 83(1), 63-73. DOI: https://doi.org/10.1007/ s10457-011-9400-9

Kanmegne, J., Bayomock, L. A., Duguma, B., \& Ladipo, D. O. (2000). Screening of 18 agroforestry species for highly acid and aluminum toxic soils of the humid tropics. Agroforestry Systems, 49(1), 31-39. DOI: https://doi.org/10.1023/A:1006334931018

Kettler, J. S. (1996). Fallow enrichment of a traditional slash/mulch system in southern Costa Rica: Comparisons of biomass production and crop yield. Agroforestry Systems, 35(2), 165-176. DOI: https://doi. org/10.1007/BF00122777

Lamarca, E. V., \& Barbedo, C. J. (2015). Desiccation sensitivity of embryos of Inga vera willd. obtaine from different environmental conditions. Revista Arvore, 39(6), 1083-1092. DOI: https://doi. org/10.1590/0100-67622015000600011

Lima, N. M., Santos, V. N. C., \& Porta, L. (2018). Quimiodiversidade, Bioatividade e Quimiossistemática do Gênero Inga (FABACEAE): Uma Breve Revisão. Revista Virtual Química, 10(3), 459-473.

Lindell, C. A., Reid, J. L., \& Cole, R. J. (2013). Planting design effects on avian seed dispersers in a tropical forest restoration experiment. 
Restoration Ecology, 21(4), 515-522. DOI: https:// doi.org/10.1111/j.1526-100X.2012.00905.x

Lopes, L. C. M., Crepaldi, M. O. S., \& Lobão, A. Q. (2017). Useful woody species and its environmental availability: the case of artisanal fishermen in Itaúnas, Brazil. Acta Scientiarum - Biological Sciences, 39(2), 227-234. DOI: https://doi.org/10.4025/actascibiolsci. v39i2.33187

LPWG. (2017). A new subfamily classification of the Leguminosae based on a taxonomically comprehensive phylogeny - The Legume Phylogeny Working Group (LPWG). Taxon, 66(1), 44-77. DOI: https:// doi.org/10.12705/661.3

Machado, S. W., de Oliveira, C. F. R., Zério, N. G., Parra, J. R. P., \& Macedo, M. L. R. (2017). Inga laurina trypsin inhibitor (ILTI) obstructs Spodoptera frugiper$d a$ trypsins expressed during adaptive mechanisms against plant protease inhibitors. Archives of Insect Biochemistry and Physiology, 95(4). DOI: https://doi. org/10.1002/arch.21393

Molares, S., \& Ladio, A. (2012). The usefulness of edible and medicinal fabaceae in argentine and chilean patagonia: environmental availability and other sources of supply. Evidence-Based Complementary and Alternative Medicine, 2012, 1-12. DOI: https://doi. org/10.1155/2012/901918

Nakajima, J. N., Soares-Silva, L. H., Medri, M. E., Goldenberg, R., \& Correa, G. T. (1996). Floristic composition and phytosociological structure in a riparian forest of Tibagi River, Telêmaco Borba, Paraná, Brazil. Arquivos de Biologia E Technologia, 39(4), 933-948.

Nimer, E. (1990). Climatologia da região sul. In E. Nimer (Ed.), Climatologia do Brasil (pp. 3-65). Rio de Janeiro, Brasil: IBGE/Departamento de Recursos Naturais e Estudos Ambientais.

Nygren, P., \& Leblanc, H. A. (2015). Dinitrogen fixation by legume shade trees and direct transfer of fixed $\mathrm{N}$ to associated cacao in a tropical agroforestry system. Tree Physiology, 35(2), 134-147. DOI: https://doi. org/10.1093/treephys/tpu116

Nygren, P., Leblanc, H. A., Lu, M. E., \& Luciano, C. A. G. (2013). Distribution of coarse and fine roots of Theobroma cacao and shade tree Inga edulis in a cocoa plantation. Annals of Forest Science, 70(3), 229-239. DOI: https://doi.org/10.1007/s13595-012-0250-z

Parisi, J. J. D., Biagi, J. D., Medina, P. F., \& Barbedo, C. J. (2016). Fungicide and drying effects on the viability of recalcitrant seeds of Inga vera subsp. affinis. Tropical Plant Pathology, 41(3), 177-182. DOI: https:// doi.org/10.1007/s40858-016-0084-6

Pennington, T. (1997). The Genus Inga. Richmond, UK: Royal Botanic Gardens Kew.
Pinto, J. M. A., Souza, E. A., \& Oliveira, D. F. (2010). Use of plant extracts in the control of common bean anthracnose. Crop Protection, 29(8), 838-842. DOI: https://doi.org/10.1016/j.cropro.2010.03.006

Pompeu, D. R., Rogez, H., Monteiro, K. M., Tinti, S. V., \& Carvalho, J. E. (2012). Antioxidant capacity and pharmacologic screening of crude extracts of Byrsonima crassifolia and Inga edulis leaves. Acta Amazonica, 42(1), 165-172.

Ragusa-Netto, J. (2004). Flowers, fruits, and the abundance of the yellow-chevroned parakeet (Brotogeris chiriri) at a gallery forest in the South Pantanal (Brazil). Revista Brasleira de Biologia, 64(4), 867-877.

Rapini, A. (2004). Modernizando a taxonomia. Biota Neotropica, 4(1), 1-4. DOI: https://doi.org/10.1590/ S1676-06032004000100002

Reitz, R. (1965). Plano de coleção. In R. Reitz (Ed.), Flora Ilustrada Catarinense (pp. 1-71). Itajaí, Brasil: Herbário Barbosa Rodrigues.

Souza, J. N. S., Silva, E. M., da Silva, M. N., Arruda, M. S. R., Larondelle, Y., \& Rogez, H. (2007). Identification and antioxidant activity of several flavonoids of Inga edulis leaves. Journal of the Brazilian Chemical Society, 18(6), 1276-1280. DOI: https://doi. org/10.1590/s0103-50532007000600025

Spadeto, C., Wilson Fernandes, G., Negreiros, D., \& Kunz, S. H. (2017). Facilitative effects of tree species on natural regeneration in an endangered biodiversity hotspot. Revista Brasileira de Botanica, 40(4), 943-950. DOI: https://doi.org/10.1007/ s40415-017-0408-x

Staver, C. (1989). Shortened bush fallow rotations with relay-cropped Inga edulis and Desmodium ovalifolium in wet central Amazonian Peru. Agroforestry Systems, 8(2), 173-196. DOI: https://doi.org/10.1007/ BF00123120

Tauchen, J., Bortl, L., Huml, L., Miksatkova, P., Doskocil, I., Marsik, P., ... Kokoska, L. (2016). Phenolic composition, antioxidant and anti-proliferative activities of edible and medicinal plants from the Peruvian Amazon. Revista Brasileira de Farmacognosia, 26(6), 728-737. DOI: https://doi:10.1016/j. bjp.2016.03.016.

Thomaz Heerdt, S., \& Ferreira de Melo Junior, J. C. (2016). Strategies of defense and level of herbivory in strata of the crown of Inga edulis Mart. (Fabaceae) in a remnant urban forest. Acta Botanica Venezuelica, 39(1), 101-117.

Tropicos. (2013). Missouri Botanical Garden. Recuperado de www.tropicos.org.

Vibrans, A. C., Sevegnani, L., Gasper, A. L., \& Lingner, D. V. (2012a). Inventário florístico florestal de Santa 
Catarina: diversidade e conservação dos remanescentes florestais. Blumenau, Brasil: Edifurb.

Vibrans, A. C., Sevegnani, L., Gasper, A. L., \& Lingner, D. V. (2012b). Inventário florístico florestal de Santa Catarina: Floresta Estacional Decidual. Blumenau, Brasil: Edifurb.

Vibrans, A. C., Sevegnani, L., Gasper, A. L, Müller, J. J. V., \& Reis, M. S. (2013a). Inventário florístico florestal de Santa Catarina: resultados resumidos. Blumenau, Brasil: Edifurb.
Vibrans, A. C., Sevegnani, L., Gasper, A. L., \& Lingner, D. V. (2013b). Inventário florístico florestal de Santa Catarina: Floresta Ombrófila Mista. Blumenau, Brasil: Edifurb.

Vibrans, A. C., Sevegnani, L., Gasper, A. L., \& Lingner, D. V. (2013c). Inventário florístico florestal de Santa Catarina: Floresta Ombrófila Densa. Blumenau, Brasil: Edifurb.

Yatazawa, M., Uchino, F., \& Hambali, G. G. (1983). Nitrogen fixing activity in warty lenticellate tree barks. Soil Science and Plant Nutrition, 29(3), 285-294. 